\title{
Assessment of Groundwater Quality of Lalitpur District, Uttar Pradesh Using GIS Mapping
}

\author{
*Pradeep Mishra \\ *M.Tech (Environmental Engineering), Bundelkhand Institute of Engineering \& Technology, Jhansi, India.
}

\begin{abstract}
Water is the mainstay of survival. No life can exist without water, since water is essential not only for existence of human beings, but also for animals, plants and all other living beings. Groundwater is the most important natural resource required for drinking to many people around the world, especially in rural areas. The aim of the present study is to provide an overview of current status of groundwater quality and to analyse spatial distribution of groundwater quality in Lalitpur district, Uttar Pradesh. Lalitpur district is the southernmost part of Uttar Pradesh, lies between $24^{\circ} 11^{\prime}$ to $25^{\circ} 14^{\prime}$ north latitude and $78^{\circ} 10^{\prime}$ to $79^{\circ} 0^{\prime}$ east longitude. The study area faces water paucity as well as water quality problems. Geographic Information System (GIS) based assessment of spatiotemporal behaviour of groundwater quality has been carried out for all blocks of Lalitpur district. The ground water quality parameters were analysed for 400 samples collected from all the blocks of Lalitpur district and then surface maps were prepared for six water quality parameters ( $\mathrm{pH}$, $T D S$, total hardness, chloride, fluoride and iron) in the ArcGIS 9.3 (spatial analyst module) to assess the quality in terms of spatial variation by interpolation between the available data, which helped to analyse the present ground water pollution scenario of the study area. The final ground water quality maps represent the ground water zones that are desirable and undesirable for drinking purpose and also identify the zones where high concentration of TDS, Hardness, chloride, iron etc are present in the study area.
\end{abstract}

Keywords: GIS, Ground water quality, Natural resource, Spatial distribution.

\section{Introduction}

Water is an essential commodity to mankind, and the largest available source of fresh water lies underground. As the world's population increases, the demand for fresh water has stimulated for the development of underground water supplies. Efforts have increased to solve these problems; methods for investigating the occurrence, patterns, and movement of ground water have been improved, better means for extracting ground water have been developed, principles of conservation have been established, and research of several types has contributed to a better understanding of the subject [1]. The shortage of surface water and the increase of water demand during the growth of population increased usage of groundwater. The assessment of ground water quality status is important for socio-economic growth and development [2]. Water quality evaluation for human consumption, agricultural and industrial activities have not been given attention especially in developing countries like India. In India, most of the population is dependent on ground water as the only source of drinking water supply [3]. The chemical composition of water is an important factor to be considered before it is used for domestic or irrigation purpose [4]. The ground water should be comparatively much clean and free from contamination than surface water. The importance of ground water quality in human health has recently attracted a great deal of interest [5]. In the developing World, $80 \%$ of all diseases are directly related to poor drinking water and unsanitary conditions [6]. It is a well-known fact that a polluted environment has a detrimental effect on health of people, animal life and vegetation [7]. Water quality is affected by a wide range of natural and human influences. The most important of the natural influences are geological, hydrological and climatic, since these affect the quantity and the quality of water available. [8].

The study area faces water scarcity as well as water quality problems. The ground water quality maps are effective tools for identifying locations which are having the threat of ground water pollution. Hence, Geographic Information System (GIS) an effective tool for groundwater quality mapping is use for assessment of spatiotemporal behaviour of ground water quality in all blocks of Lalitpur district. The present study used the Inverse Distance Weighted (IDW) method for spatial interpolation of the chemical indices. The ground water quality parameters are analysed for 400 samples collected from all the blocks of Lalitpur district and then surface maps are prepared for six water quality parameters ( $\mathrm{pH}$, TDS, total hardness, chloride, fluoride and iron) in the ArcGIS 9.3 (spatial analyst module). Each map is classified based on the BIS norms and it shows that Iron is major problem in the study area, especially in Talbehat and Birdha block. It is noted that quality of ground water in Lalitpur exceeds Indian standards for drinking water on the basis of measured values of TDS and Total hardness. A complementary objective of this study was to demonstrate the GIS capabilities in exploring the full value of ground water quality data through spatial analysis and visual display of geographic information. 


\section{Study Area}

The area under investigation is located within district Lalitpur, which is a part of Bundelkhand area of Uttar Pradesh. In all blocks of the district, ground water development takes place through dugwells, borewells and state tubewells. In Lalitpur district, number of tanks, ponds and reservoirs had been constructed taking advantage of the typical physiography and drainage by constructing dams across the major and minor streams, with an objective to store water for irrigational and domestic purposes.

Lalitpur district is a drought prone and backward region of U.P. The life of the habitants become miserable when the water supply sources like dugwells, ponds \& tanks etc. get dry due to failure of monsoon. The latitude of study area ranges from $24^{\circ} 11^{\prime} \mathrm{N}$ to $25^{\circ} 14^{\prime}$ and longitude ranges from $78^{\circ} 10^{\prime} \mathrm{E}$ to $79^{\circ} 00^{\prime} \mathrm{E}$, with area of coverage 1160 hectares. In 2006 the Ministry of Panchayati Raj named Lalitpur one of the country's 250 most backward districts (out of a total of 640) [9]. Women in villages of Lalitpur suffer most as they have to walk more than $2 \mathrm{kms}$ to fetch drinking water needs. Thousand of households in rural areas in Lalitpur wake up in the pre-dawn to fetch water from hand pumps, which are for away from their houses. In the study area, the situation of water supply has become more problematic, with rapid increase in population and decrease in rainfall.

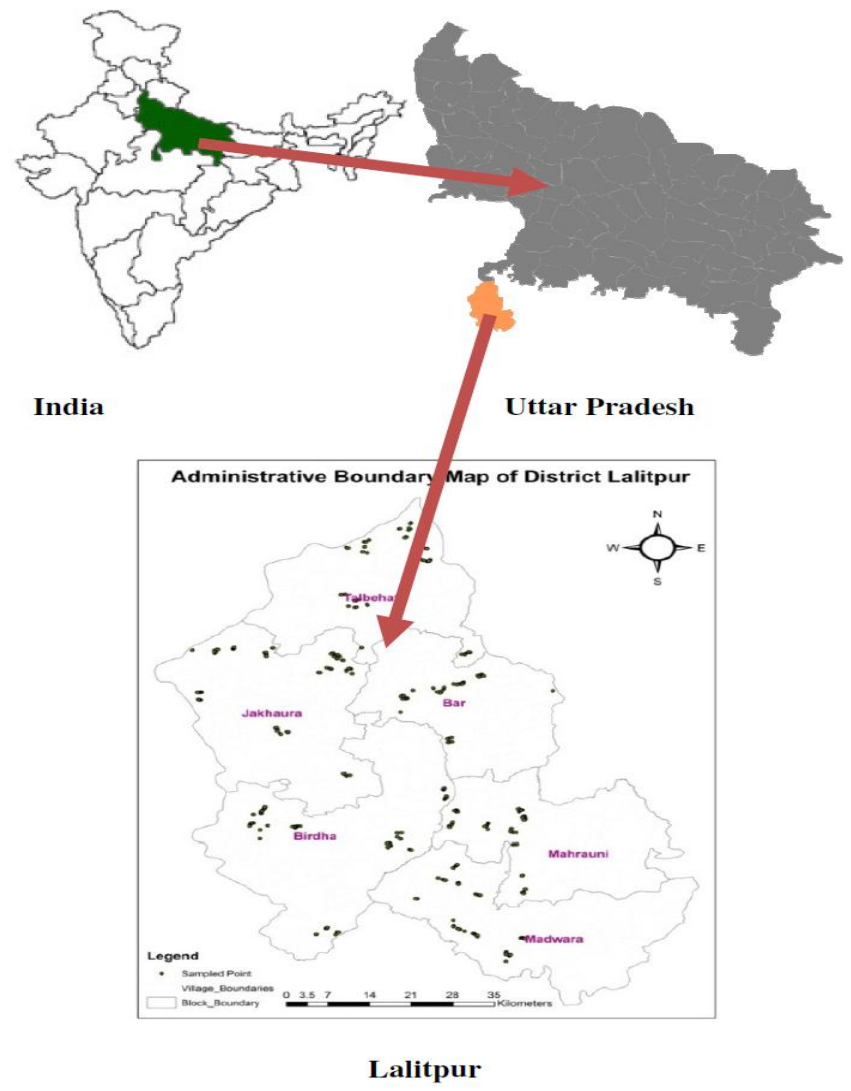

Fig 1: Map showing location of Lalitpur District

\section{Methodology}

Study methodology is broadly divided into three parts:

1. Groundwater sampling point, sample collection and analysis.

2. Geo-data base creation by ArcGIS 9.3 software.

3. Spatial Modeling and Surface Interpolation through IDW.

1. Groundwater sampling point, sample collection and analysis: The boundary of the Lalitpur District is digitized from the Uttar Pradesh administrative map. Spatial coordinates and levels of sampling points are measured on site using a hand held GPS instrument GARMIN GPS-60 and the results were taken to the GIS for further analysis. Total 400 sampling point were selected for all six blocks of Lalitpur District as shown in Figure 


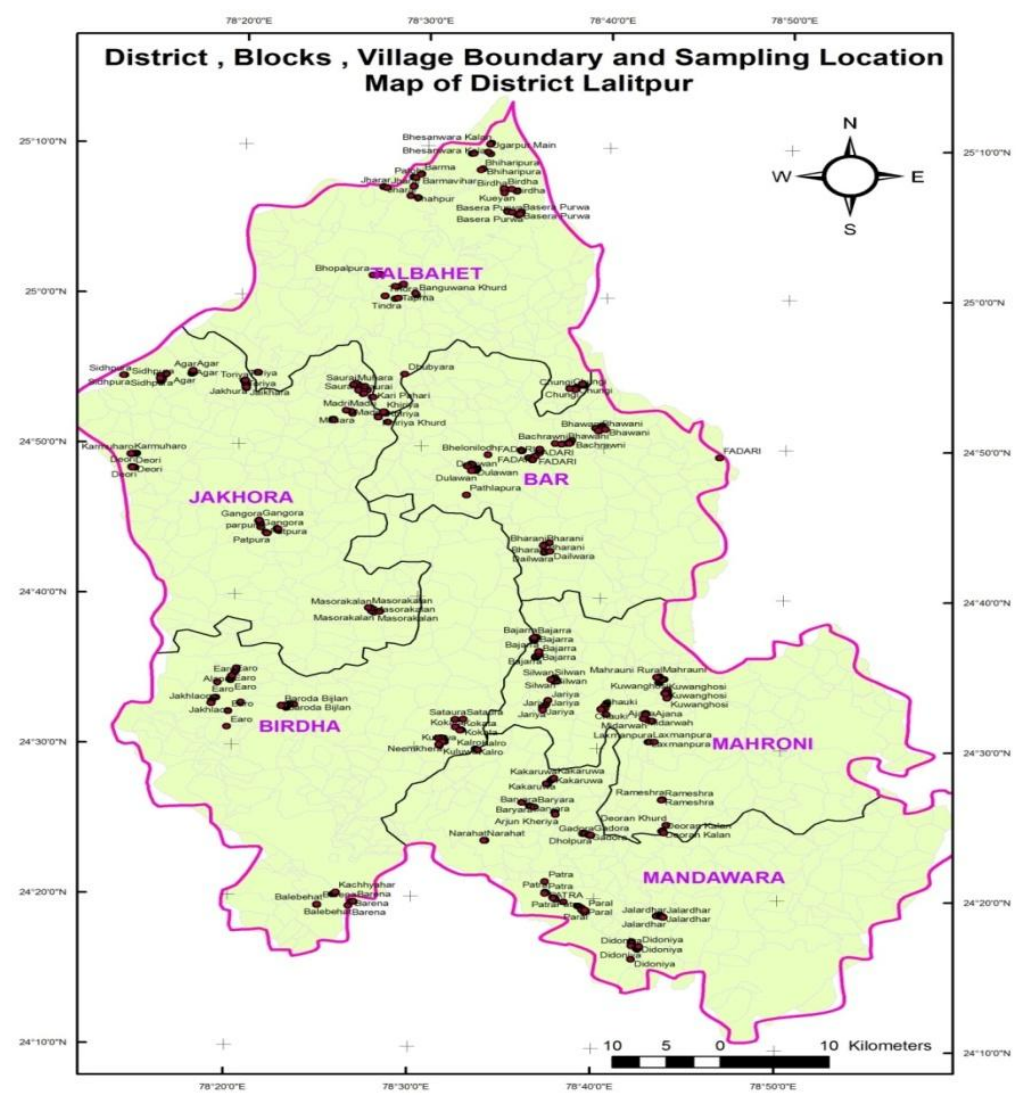

Fig 2: Map showing sampling locations

The ground water samples were collected manually from the hand pumps which are being extensively used for drinking and other domestic purposes. The statistics of samples collected are given in Table 1. The ground water samples were collected directly from hand pumps after pumping few strokes for $2 \mathrm{~min}$. This was done in order to remove ground water stored in the pipe of hand pumps. Water samples were collected in 1000$\mathrm{mL}$ polyethylene terephthalate (PET) bottles and transported to the laboratory on ice in cooler boxes. The water samples were collected and analysed during the period of April 2012 to October 2012 and GPS survey was done.

\begin{tabular}{|l|l|}
\hline Name of the block & Number of samples \\
\hline Bar & 52 \\
\hline Birdha & 80 \\
\hline Jakhaura & 90 \\
\hline Madavra & 65 \\
\hline Maharauni & 60 \\
\hline Talbehat & 53 \\
\hline Total & $\mathbf{4 0 0}$ \\
\hline
\end{tabular}

Table 1: Statistics of Samples Collected

The collected samples were analysed in the Environmental Engineering Laboratory (Civil Engineering Department) at B.I.E.T., Jhansi. The Parameters analysed during water analysis, were $\mathrm{pH}$, Chloride, Fluoride, Iron, Total hardness, and TDS. Water quality parameters were analysed in the laboratory according to the methods given in APHA 1998 [10].

\begin{tabular}{|r|l|l|l|}
\hline S.N. & Parameters & Instrument used & Methods \\
\hline $\mathbf{1 .}$ & $\mathrm{pH}$ & $\mathrm{pH}$ meter & Recorded by $\mathrm{pH}$ meter \\
\hline $\mathbf{2 .}$ & Chloride & - & Argentometric Titrimetric Method \\
\hline $\mathbf{3 .}$ & Fluoride & Spectrophotometer & Colorimetric SPANDS Method \\
\hline $\mathbf{4 .}$ & Iron & Spectrophotometer & Colorimetric Phenonthroline Method \\
\hline $\mathbf{5 .}$ & Total hardness & - & EDTA Titration \\
\hline $\mathbf{6 .}$ & TDS & Thermogravimetry, Analytical Balance & Gravimetric Method \\
\hline
\end{tabular}

Table 2: Specific Methods of Estimation of Different Physico-chemical Parameters of Groundwater in the Study Area 
2. Geo-data base creation by ArcGIS 9.3 software: The geo-database was used to generate the spatial distribution maps of the chemical indices. The different locations of the sampling points were imported into GIS software through point layer. The map showing sampling points was scanned and imported into ArcGIS version 9.3 and was geo-referenced and digitized. Data for selected parameters were linked to the sampling locations using the geo-data base creation function of ArcGIS 9.3 software.

3. Spatial modeling and surface interpolation through IDW: GIS technology allows the organization, manipulation, analysis, and visualization of spatial data, often uncovering relationships, patterns, and trends. There are a number of spatial modeling techniques available with respect to application in GIS, spatial interpolation technique through Inverse Distance Weighted (IDW) approach has been used in the present study for spatial interpolation of the chemical indices.

\section{Results And Discussion}

Interpretation of water quality parameter helps to maintain a healthy society and surroundings in which ground water requires more attention as level and quality is dropping exponentially. The variations of the physicochemical characteristics of the ground water in the different blocks of Lalitpur district are presented through figures 3 to 8 . Understanding the quality of groundwater is important in order to determine its suitability for drinking, domestic, agricultural and industrial purposes. And groundwater quality maps were created for each parameter.

\section{Spatial Distribution Of Water Quality Parameters}

pH: $\mathrm{pH}$ is one of the most important operational water quality parameter. The optimum $\mathrm{pH}$ required often being in the range of 7.0-8.5. The maximum permissible limit of $\mathrm{pH}$ for drinking water as given by the BIS - 10500 (2004-2005) is 8.5 .

The Interpolated Distance Weighted (IDW) map presented in figure 3 shows the spatial distribution of $\mathrm{pH}$ in Lalitpur district. 12\% sample of Jakhaura block, 4\% sample of Bar block and $1.8 \%$ of sample Talbehat block are found to have $\mathrm{pH}$ below permissible limit (6.5). Only one sample of village Biharipura, Ugarpur panchayat of Talbehat block shows $\mathrm{pH}$ above 8.5.

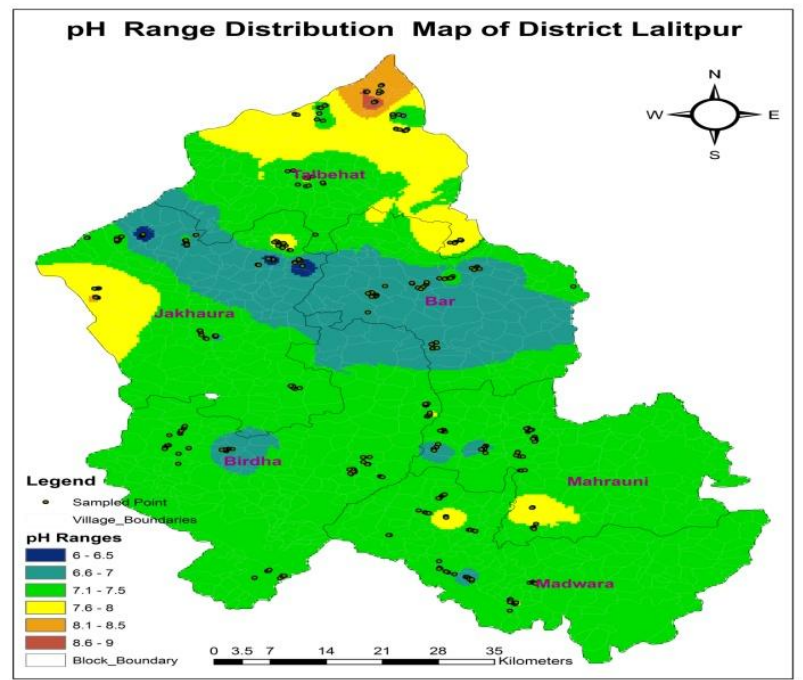

Fig 3: Spatial distribution of $\mathrm{pH}$ in the study area

Total Dissolved Solids (TDS): TDS in water are represented by the weight of residue left when a water sample has been evaporated to dryness [11]. The maximum permissible limit for TDS for drinking water as given by the BIS -10500 (2004-2005) is below 500mg/l. Beyond this Palatability decreases and may cause gastro intestinal irritations.

Interpolated Distance Weighted (IDW) map presented in figure 4 shows the spatial distribution of TDS in Lalitpur district. More than $65 \%$ samples have TDS value above $500 \mathrm{mg} / \mathrm{l}$. 


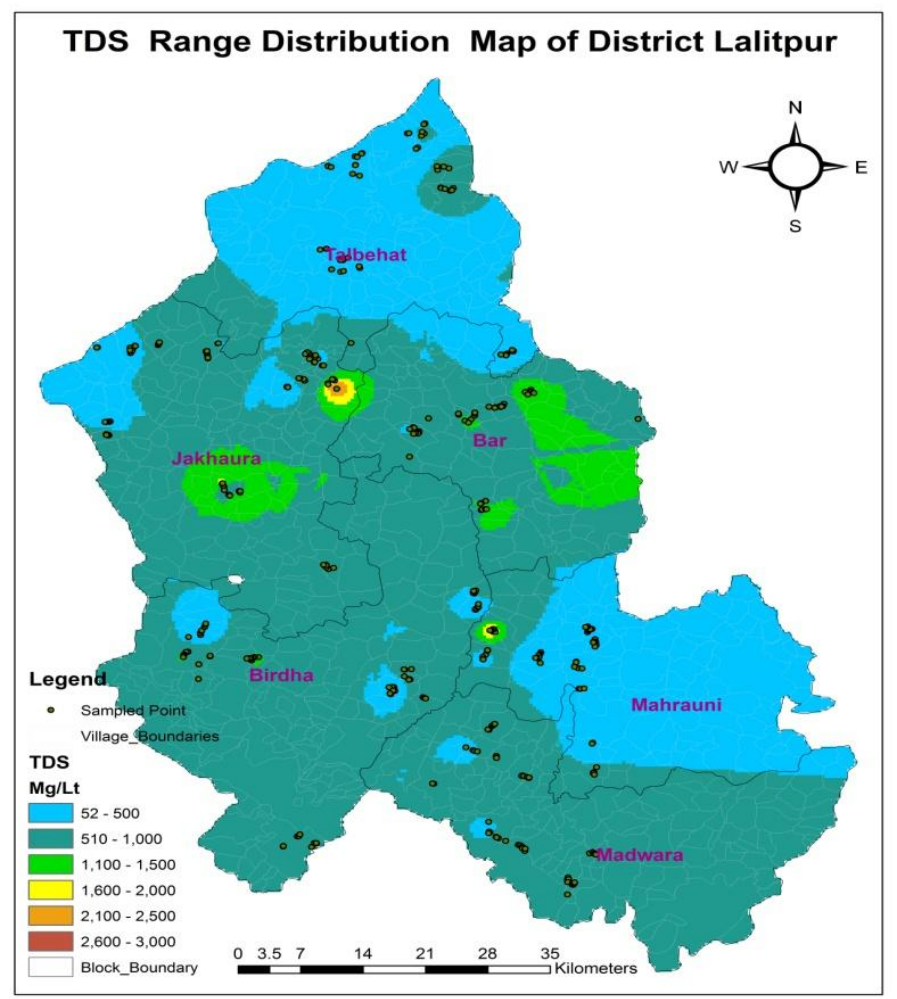

Fig 4: Spatial distribution of TDS in the study area

Total Hardness (TH): Hardness is defined as the concentration of multivalent metallic cations in solution. At supersaturaturated condition, the hardness cations will react with anions in the water to form a solid precipitate [12]. The hardness of good quality water should not exceed $270 \mathrm{mg} / \mathrm{l} \mathrm{measured} \mathrm{as} \mathrm{calcium} \mathrm{carbonate}\left(\mathrm{CaCO}_{3}\right)$. Water softer than 30-50 mg/l may be corrosive to piping, depending on $\mathrm{pH}$, alkalinity and dissolved oxygen. Whether or not to soften hard water is a matter of personal preference and depends on the natural sodium level.

The Interpolated Distance Weighted (IDW) map presented in figure 5 shows the spatial distribution of Total Hardness in Lalitpur district. The study clearly indicates that TH value range is from 26 to $1246 \mathrm{mg} / \mathrm{l}$. Map obtained shows that more than $60 \%$ of the samples are exceeding the permissible limit of $300 \mathrm{mg} / \mathrm{l}$ set by BIS10500 (2004-2005).

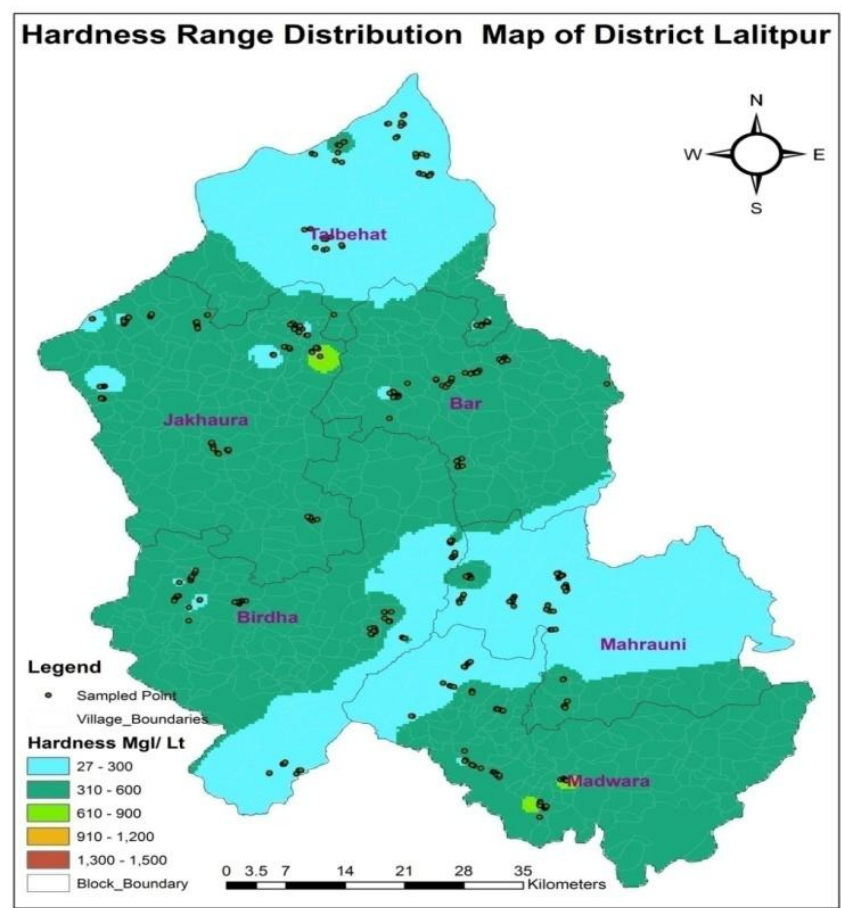

Fig 5: Spatial distribution of Total Hardness in the study area 
Chloride: Chloride is one of the most important parameter in assessing the water quality and higher concentration of chloride indicates higher degree of organic pollution [13]. According to BIS-10500 (20042005) permissible limit of chloride in drinking water is $250 \mathrm{mg} / 1$.

The Interpolated Distance Weighted (IDW) map presented in figure 6 shows the spatial distribution of Chloride in Lalitpur district. Most of the samples of district have chloride value within range. Only few samples of Jakhaura block have very high value of chloride.

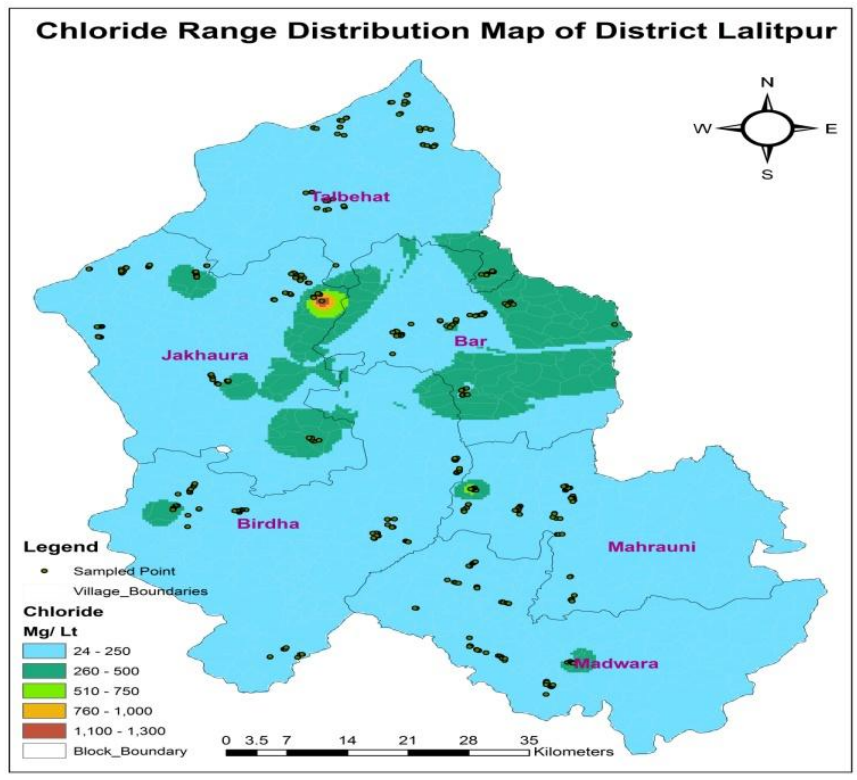

Fig 6: Spatial distribution of Chloride in the study area

Fluoride: Fluoride, the most commonly occurring form of fluorine, is the natural contaminant of water. Ground water usually contains fluoride, dissolved by geological formation. Exposure to excessive consumption of fluoride over a lifetime may lead to increased likelihood of bone fractures in adults, and may result in effects on bone leading to pain and tenderness. Children aged 8 years and younger exposed to excessive amounts of fluoride have an increased chance of developing pits in the tooth enamel, along with a range of cosmetic effects to teeth [14]. And a fluoride concentration of less than $0.8-1.0 \mathrm{mg} / \mathrm{l}$ may be harmful and may cause dental caries (tooth decay) among young children during calcinations of their permanent teeth. Higher fluoride concentrations, greater than $1.5 \mathrm{mg} / \mathrm{l}$ or so may again be harmful, causing spotting and discolouration of teeth, which with continued excessive consumption of fluorides, may even cause deformation of bones [15].

The Interpolated Distance Weighted (IDW) map presented in figure 7 shows the spatial distribution of Fluoride in Lalitpur district. The concentration of fluoride is below $1 \mathrm{mg} / \mathrm{lit}$ in most of the villages. Talbehat block have many locations with fluoride above $1.5 \mathrm{mg} / \mathrm{l}$ which shows greater possibilities of spotting and discolouration of teeth. Continual use of such sources may also cause deformation of bones. $25 \%$ sample found to have concentration below $0.5 \mathrm{mg} / 1$ which may cause dental caries in children.

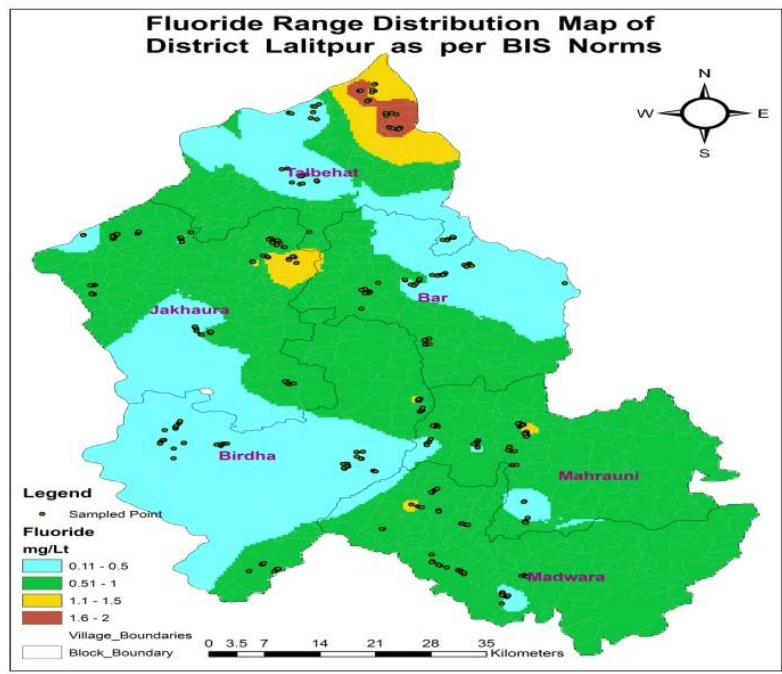

Fig 7: Spatial distribution of Fluoride in the study area 
Iron: The primary source of iron is the water bearing strata. Iron is typically dissolved in water and when brought to the surface, can form "rust" which may settle out. Another source of iron is iron-reducing bacteria, which depend upon iron to live. These bacteria add iron to the water by attacking the piping of the system. Removing naturally-occurring iron in the water may require special water treatment equipment. Iron-reducing bacteria may be controlled or eliminated by adequate chlorination. Ground water that contain appreciable amount of iron are always devoided of dissolve oxygen and contain high carbon dioxide which is harmful. These are usually due to the presence of iron above $0.3 \mathrm{mg} / \mathrm{l}$.

The Interpolated Distance Weighted (IDW) map presented in figure 8 shows the spatial Distribution of Iron in Lalitpur district. In terms of iron Jakhaura shows admirable condition as all the samples are within permissible range while that of Talbehat, Birdha and Madwara shows miserable condition, here almost all samples sample shows very high value of iron. Although Bar and Mahrauni blocks also shows better condition still Jakhaura block considered the best and Talbehat block the worst.

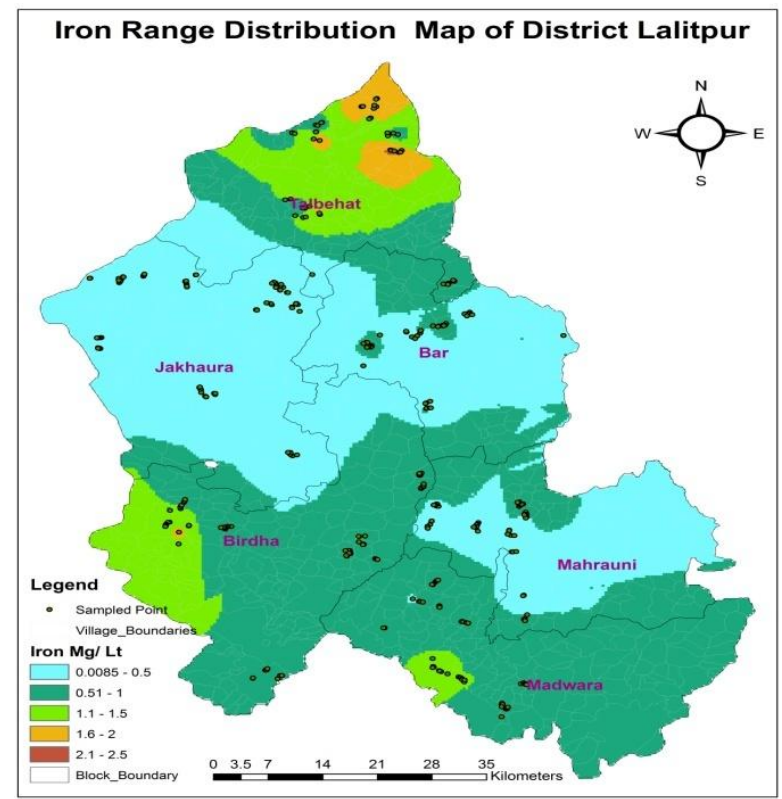

Fig 8: Spatial distribution of Iron in the study area

\section{Conclusion}

It is essential to monitor ground water quality extensively in rural areas on a regular and scientific basis. An attempt has been made in this study to describe ground water quality of Lalitpur district, Uttar Pradesh with a GIS perspective and geo referenced ground water database and maps are developed which are useful for formulating sustainable ground water use policies and public health projects. The analysis of the results drawn from the work revealed that GIS is an effective tool for the preparation of maps showing the spatial distribution of water quality parameters. Moreover, GIS makes the ground water quality maps in an easily understood format. The spatial distribution analysis of ground water quality indicated that many of the samples collected are not satisfying the drinking water quality standards prescribed by the Indian Standards for drinking water. Some locations of Talbehat and Jakhaura block show very low potability.

It is shown that groundwater of study area presented a $\mathrm{pH}$ value within the maximum permissible limit. The TDS values of Jakhaura, Bar and some locations of Mahruani block are high while the rest of study areas have moderate values of TDS. In our study, spatial distribution map of TH shows that majority of the ground water samples falls in the very hard category except in Talbehat and Maharauni block where water is comparatively soft. It is found that except Bar and Jakahura block, overall chlorides concentration are not problematic. In Jakahura block, it is noticed that maximum concentration of chloride is $3207.006 \mathrm{mg} / \mathrm{l}$ which is very high and it may be due to soil characteristic and pollution from domestic wastes. For such samples, it is suggested to checkout further variation for better result because in this study one time sampling for one source is done. As for as fluorides concern, except for some location of Talbehat, fluorides concentration are not high but in Birdha and some areas of Bar and Talbehat block fluorides concentration are less than that of $0.5 \mathrm{mg} / 1$, which needed further addition of fluoride. Iron concentration in Talbehat, Birdha and Madwara block is very high compared to Indian standards. So, it is suggested to filter or add lime to the water prior to use for drinking purpose. And after filtration, if unpleasant taste of water still remains then it is recommended to find other alternative source. 
Further study is necessary to determine the seasonal variations in ground water quality parameters, because in some areas of Talbehat and Jakhaura block result shows dramatic change in water quality for some parameters. An excessive use of fertilizers and pesticides in agriculture practice were noticed during the field work. Hence proper attention should be given to water quality monitoring along with ground water resource development. This study has shown that the use of GIS is very useful tool for the assessment of ground water quality.

\section{Recommendations}

For preventing further ground water quality deterioration a regular monthly/seasonal sampling of ground water and analysis for physico-chemical and bacteriological test is recommended for safeguarding public health and effective ground water quality management. It requires a complete identification of ground water recharging locations and structures. For this purpose, Geographical Information System (GIS) with the required spatial and non-spatial data can be used very well as the tool. Continuous monitoring of ground water table level along with quality will minimize the chances of further deterioration. Women, and general public should be addressed about the ground water quality not satisfying the water quality requirements as per BIS - 10500 (2004-2005) and advising them for avoiding the use of untreated groundwater.

\section{Acknowledgements}

Author sincerely acknowledges support provided by Dr. A. K. Srivastava (associate professor), Department of Civil Engineering, Bundelkhand Institute of Engineering \& Technology, Jhansi, Mr. Amit Amehrotra, WASH specialist, UNICEF UP and Mr. Naveen Shukla, water safety consultant, UNICEF UP during this study. The work was funded by the UNICEF UP. The financial support from UNICEF UP for carrying out this study is gratefully acknowledged.

\section{References}

[1]. Todd, David. K, Groundwater Hydrology (New York, J. Wiley \& Sons, 1959).

[2]. Ishaku1 J.M., Ahmed A.S. and Abubakar M.A. (2011), "Assessment of groundwater quality using chemical indices and GIS mapping in Jada area, Northeastern Nigeria”. Journal of Earth Sciences and Geotechnical Engineering, vol. 1, no. 1, 2011, 35-60. ISSN: 1792-9040(print), 1792-9660 (online) International Scientific Press, 2011

[3]. Mahmood A, Kundu A (2005). India's demography in 2050: size, structure and habitat. Discussion Paper, IWMI-TATA partners meet - 2005, Anand, Gujarat.

[4]. Suresh T.S., Naganna C. and Srinivas G., (1991), Study of water quality for agricultural use in Hemavathyriver (Karnataka). Hydrol. J. Indian Assoc. Hydrol., 14(4): 247-254.

[5]. Vasanthavigar M., Srinivasamoorthy K., R. Rajiv Gantha, Vijayaraghavan K. and Sharma V.S., (2010), Characterization and quality assessment of groundwater with special emphasis on irrigation utility: Thirumanimuttar sub-basin, Tamil Nadu, India. Arab GeosciJ, DOI 10 1007/s12517-010-0190-6.

[6]. UNESCO, (2006), UNESCO water portal newsletter no. 161: Water-related diseases. Available at: http//www.unesco.org/water/news/newsletter/161.shtml.

[7]. Sujatha D., Rajeswara Reddy B., (2003), "Quality characterization of groundwater in the south-eastern part of the Ranga Reddy district, Andhra Pradesh", Indian Journal of Environmental Geology, 44, pp 579-586.

[8]. Sundara Kumar K., Sundara Kumar P., Dr. M. J. Ratakanth Babu and Dr. Rao. “Assessment and mapping of ground water quality using geographical information system”. K.Sundara Kumar et. al. / International Journal of Engineering Science and Technology. Vol. 2(11), 2010, 6035-6046.

[9]. Ministry of Panchayati Raj (September 8, 2009). "A Note on the Backward Regions Grant Fund Programme" (http://www.nird.org.in/brgf/doc/brgf_BackgroundNote.pdf). National Institute of Rural Development. Retrieved September 27, 2012.

[10]. APHA, AWWA, WPCF: Standard Methods for the Examination of Water and Wastewater.( Washington, USA, 20th Edition, , 1998).

[11]. World Health Organization (WHO)(2006). Guidelines for Drinking-water Quality,

URL:http://www.who.int/entity/water_sanitation_health/dwq/gdwq0506.pdf.

[12]. Peavy and Rowe, Environmental Engineering (Singapore, Mcgraw-Hill International Edition, 1985)

[13]. Yogendra K., and Puttaiah E.T. (2008), Determination of water Quality Index and Suitability of urban water body in Shimoga Town, Karnataka. The 12th world lake conference, pp 342-346.

[14]. USEPA, http://water.epa.gov/drink/contaminants/basicinformation/fluoride.cfm (Assessed on 06/09/2013).

[15]. Garg S.K., Water Supply Engineering ( New Delhi, Khanna Publishers, 2011). 